\title{
EFL LEARNING STYLES AND STRATEGIES OF UNIVERSITY STUDENTS
}

\author{
Dalia Gulbinskienè \\ General Jonas Žemaitis Military Academy of Lithuania \\ Assoc. Prof. Dr. Giedrẻ Valūnaitė Oleškevičienė
}

Mykolas Romeris University

\begin{abstract}
Each of us has our own preferred way of learning that is determined by our cultural and educational background and our personalities. We have often wondered why we have difficulties learning a foreign language from a particular teacher, whereas others seem to explain things in just the right way. There is a question why the course that someone recommends as an easy one turns into a very complicated one for another person. The reason for these discrepancies may be the differences in learning styles. People learn most effectively when the strategies used are closely matched with their preferred learning style. Sometimes we can improve our learning by knowing our strengths and then doing more of what we are good at. But it is also important to know our weaknesses in order to enhance our skills in these areas. When English teachers try to improve the effectiveness of students' work, they should be aware of the main learning strategies that best match the way students like to learn and check to see if they follow suggested strategies. Thus, teachers can help foreign language students develop their natural style of learning. The current study investigates the diverse learning styles and strategies employed by EFL students at the researched Lithuanian university. The research reveals that students employ the perceptual learning style and the compensation language learning strategy prevails among students.
\end{abstract}

Keywords: language learning styles, language learning strategies, EFL.

\section{Introduction}

Language learning styles are general approaches to learning a language, and strategies are specific behaviors or thoughts learners use to enhance their language learning. These factors influence the student's ability to learn in a particular instructional framework. Learning style or learning preference is the way you tend to learn best. It involves your preferred method of taking in, organizing, and making sense of information. Learning styles do not tell us about a person's abilities or intelligence, but they can help us understand why some tasks seem easier for us than 
others. Learning styles are general approaches - for example, global or analytic, auditory or visual - that students use in acquiring a new language or learning any other subject. These styles are the overall patterns that give general direction to learning behavior. A learning style is an imposed set of characteristics that makes the same teaching method wonderful for some and terrible for others. There are different aspects of a learning style, such as sensory preferences, personality types, desired degree of generality, and biological differences.

Learning strategies are defined as "specific actions, behaviors, steps, or techniques - such as seeking out conversation partners or giving oneself encouragement to tackle a difficult language task - used by students to enhance their own learning" (Oxford, 2003). When the learner consciously chooses the strategies that fit his or her learning style and the task at hand, these strategies become a useful toolkit for active, conscious, and purposeful self-regulation of learning.

The object of the research is the EFL learning styles and strategies of university students. The aim of the study is to determine the preferred language learning styles and strategies of the researched Lithuanian university students and thus give some recommendations, based on the research findings, on how the EFL teachers could better organize their classes. The following objectives of the research are set: 1) to prepare and distribute a questionnaire on language learning styles and strategies; 2) to perform a quantitative analysis of language learning styles and strategies; 3 ) to prepare some tentative recommendations for the EFL teachers based on the research findings.

\section{Literature Review}

Different scholars distinguish different language learning styles. However, Brown (1994) distinguishes three main learning style preferences: auditory (learning by hearing), visual (learning by seeing), and kinesthetic (learning by doing). Visual learners usually enjoy reading and prefer to see the words that they are learning. They also like to learn by looking at pictures and flashcards. Auditory learners prefer to learn by listening. They enjoy conversations and the chance for interactions with others. They do not need to see the words written down. A recent study found that Koreans and Japanese students tend to be visual learners, whereas English-speaking Americans prefer the auditory learning style. Tactile or kinesthetic learners learn by touching and manipulating objects known as "hands-on" work. They like movement and need frequent breaks in desk activities. Moreover, Oxford (2010) distinguishes some more learning styles. Field-independent learners, also called analytic learners, like to concentrate on the details of language, such as grammar rules, and enjoy taking apart words and sentences. They are sometimes unable to see the "big picture" because of their attention to its parts. Field-dependent learners, also known as global learners, focus on the whole picture and do not care so much about the details. For example, 
they are more interested in conveying an idea than worrying about whether it is grammatically correct. Reflective learners like to think about language and how to convey their message accurately. They tend not to make so many mistakes because they take time in formulating what they want to say. Impulsive learners take risks with the language. They are more concerned about speaking fluently than speaking accurately and make more mistakes.

Willing (1994) identified four major learning styles: communicative, analytical, authority-oriented and concrete. Communicative learners were defined by the following learning strategies: they like to learn by watching, listening to native speakers, talking to friends in English, watching television in English, using English out of class, learning new words by hearing them, and learning by conversation. Analytical learners like studying grammar, reading English books and newspapers, studying alone, finding their own mistakes, and working on problems set by the teacher. Authority-oriented learners prefer the teacher to explain everything, having their own textbook, writing everything in a notebook, studying grammar, learning by reading, and learning new words by seeing them. Concrete learners tend to like games, pictures, films, videos, using cassettes, talking in pairs, and practicing English outside class.

Scholars suggest employing different activities according to the students' learning styles. Vernon (2016) and Razawi et al. (2011) state that if a group of students prefers learning by hearing, they have to use the strategy called enhancing auditory learning. Therefore, the students should listen to instructions and information given orally, sit towards the front of the room so they can hear well and so that they are not distracted by different sources of noise, and repeat information silently to themselves. The right strategies for language learning could be the following: rehearsing information either mentally or out loud, studying with a partner and taking turns reading to each other and discussing key concepts, working in quiet areas to minimize music noise or other distractions, using rhymes or jingles to help remember important points, using textbook diagrams and illustrations, and reading instructions and questions out loud to themselves.

When the preferred learning style is visual, the proposed strategy is enhancing visual learning. That is, during language classes students should watch for key words written on PowerPoint slides or the board to help organize notes, listen and write down what they hear, fill in their notes and check for understanding after each class, use visuals like symbols and colors in notes, ask the instructor for clarification of details or if other visual information is available.

In contrast, kinesthetic students are comfortable without visual input and, therefore, enjoy and profit from conversations and oral directions. They are excited by classroom interactions in role plays and similar activities. As a rule, they usually ask questions and participate in discussions, think of the relevance and applicability of the course themselves and life in general, use a laptop to take notes, etc. They like lots of movement and enjoy working with tangible objects, collages, 
and flashcards. Sitting at a desk for very long is not for them as they prefer to have frequent breaks and move around the room. So, this group of students learns by doing. It should be mentioned that they typically use their hands when talking to people, try using their hands and gestures when studying and explaining concepts to themselves.

When a learner consciously chooses the strategies that fit his or her learning style, they become a useful tool for active, conscious, and purposeful self-regulation of learning. If there is a harmony between the student and the combination of instructional methodology and materials, then the student is likely to perform well and feel confident. Therefore, the foreign language instructor's purpose is to help students determine their learning style and work out an appropriate method of a language teaching.

Every task and exercise is usually underpinned by at least one learning strategy, although in most classrooms learners are unaware of these strategies. One of the hypotheses tested by learning strategy researchers is that awareness and deployment of strategies will lead to a more effective language acquisition. The goal of learning strategies is to affect the learner's motivational or affective state, or the way in which the learner selects, acquires, organizes, or integrates new knowledge. Learning strategies enable students to take more responsibilities of their own language learning and personal development.

Oxford (2006) draws a distinction between direct and indirect strategies. Direct strategies include memorizing, analyzing, reasoning and guessing intelligently. These are specific procedures that learners can use to improve their language skills. Indirect strategies, on the other hand, include things, such as evaluating one's learning and cooperating with others.

Learning styles are general approaches to language learning, while learning strategies are specific ways to deal with language tasks in particular contexts (Oxford, 2003). The research perhaps most closely related to the links between learning styles and strategies is Oxford's study on the five learning style contrasts identified styles: visual versus auditory (the use of physical senses for study and work), extroversion versus introversion (dealing with other people), intuitiverandom versus concrete-sequential (handling possibilities), closure-oriented versus open (approaching tasks), and global versus analytic (dealing with ideas). Each of the five style contrasts constitutes a comparative style continuum. It is important for learners to identify these learning styles and recognize their strengths and thus expand their learning potential. Oxford notes that once learners are aware of their own learning styles, it enables them to adapt their learning strategies to suit different learning tasks in particular contexts. Learners can take advantages of their learning styles by matching learning strategies with their styles; similarly, learners can compensate for the disadvantages of their learning styles to balance their learning by adjusting learning strategies.

The strategies that fulfill these conditions make learning easier, faster, 
more enjoyable, more self-directed, more effective, and more transferable to new situations. Learning strategies can also enable students to become more independent, autonomous, and lifelong learners.

Oxford (2003) identifies six broad categories of strategies:

1. Metacognitive (e.g. self-monitoring, paying attention)

2. Affective (e.g. self-encouragement, anxiety reduction)

3. Social (e.g. ask questions, become culturally aware)

4. Memory (e.g. grouping, imagery, associating)

5. Cognitive (e.g. reasoning, analyzing, summarizing)

6. Compensation (e.g. guessing meanings, using synonyms)

In addition, students could use strategies, such as skimming for the main points, reading carefully for supporting details, keeping a notebook for scientific vocabulary, using a dictionary to look up for difficult words, guessing the meaning of words from the context, and making a written outline or summary, if needed.

Cognitive strategies enable learners to manipulate language material in direct ways through reasoning, analysis, note-taking, summarizing, synthesizing, outlining and reorganizing information to develop stronger knowledge structures. Metacognitive strategies or identifying one's own learning style preferences and needs, planning for a language task, gathering and organizing materials, arranging a study space and a schedule, monitoring mistakes, and evaluating task success are employed for managing the overall learning process. Metacognitive strategies have a significant and positive direct effect on the cognitive strategy use providing clear evidence that metacognitive strategy use has an executive function over cognitive strategy use in task completion (Purpura, 1999). Memory-related strategies help learners link one item or concept with another but do not necessarily involve deep understanding. Various memory-related strategies enable learners to learn and retrieve information in an orderly string, while other techniques create learning and rhyming, images, a combination of sounds and images, body movement, mechanical means, or location. However, memory-related strategies do not always positively relate to language proficiency. In fact, the use of memory strategies in a test-taking situation has a significant negative relationship to learners' test performance in grammar and vocabulary (Purpura, 1999). A probable reason for this is that memory strategies are often used for memorizing vocabulary and structures in the initial stages of language learning, but learners need such strategies much less when their arsenal of vocabulary and structures becomes larger. Compensatory strategies are guessing from the context in listening and reading, using synonyms and "talking around" the missing word to aid speaking and writing; and strictly for speaking and using gestures. They help learners make up for missing knowledge. Affective strategies involve identifying one's mood and anxiety level, talking about feelings, rewarding oneself for good performance, and using deep breathing or positive selftalk. Social strategies are asking questions to get verification or clarification of a 
confusing point, asking for help in doing a language task, talking with a nativespeaking conversation partner, and exploring cultural and social norms. They help learners work with others and understand the target culture as well as the language. Useful means exist to make these assessments, as mentioned earlier.

Various studies were carried out on the relationship between the strategy use and various variables, such as age, learner styles, proficiency, motivation and culture. Some researchers, like Wong and Nunan (2011), found out that older learners used some strategy categories more often than the younger ones. Out of the six Oxford categories of strategies, memory, affective, metacognitive, and social strategies are used more often by older learners, who use cognitively complex strategies, whereas young learners prefer social strategies. Some researchers focused on the relationship between language learning strategies and learner styles. Studies show that teaching language learning strategies improve reading and speaking proficiency and advanced level students use more language learning strategies than elementary students. Literature also show that more motivated learners use a wider range of strategies or some categories more often than less motivated learners (Oxford, 1999). Also, there is evidence that culture affects the use of language learning strategies. Memory strategies are infrequently used by Asian learners, and European learners use more strategies than learners of other nationalities.

\section{Research Methodology}

The study aimed at the EFL learning styles and strategies of university students. It was exploratory in nature, so improbable convenient and targeted selection was used by choosing student groups studying English. However, in the follow-up study, a random selection of faculties and student group will be applied. A set of questionnaire was distributed to 77 students of Kazimieras Simonavičius University, and as it was an exploratory study, it was limited to a smaller number of questionnaires. The respondents were students of Marketing and Advertising, Fashion Industry, and Economics, aged 19-25. In an effort to ensure the reversibility of the questionnaires, English teachers were personally contacted during the survey and requested assistance in the distribution of polls. The reversibility of the questionnaires was high (94\%) because the teachers were addressed in person asking to distribute the questionnaire to students they teach. The questionnaire was designed to comply with the principle of friendliness: the statements were formulated based on the principle of positive sentences. 


\section{Research Findings}

The respondents had to choose from 8 language learning styles. Figure 1 shows their preferences: $35 \%$ of auditory learners, $17 \%$ of visual learners, $16 \%$ of reflective learners, $14 \%$ of impulsive learners, $10 \%$ of field-dependent learners, $3 \%$ of kinesthetic learners, $2 \%$ of field-independent learners and only $1 \%$ of tactile learners. Consequently, the EFL teachers should take into consideration the fact that more than one third of the students learn English through listening.

\section{Preferred language learning styles}

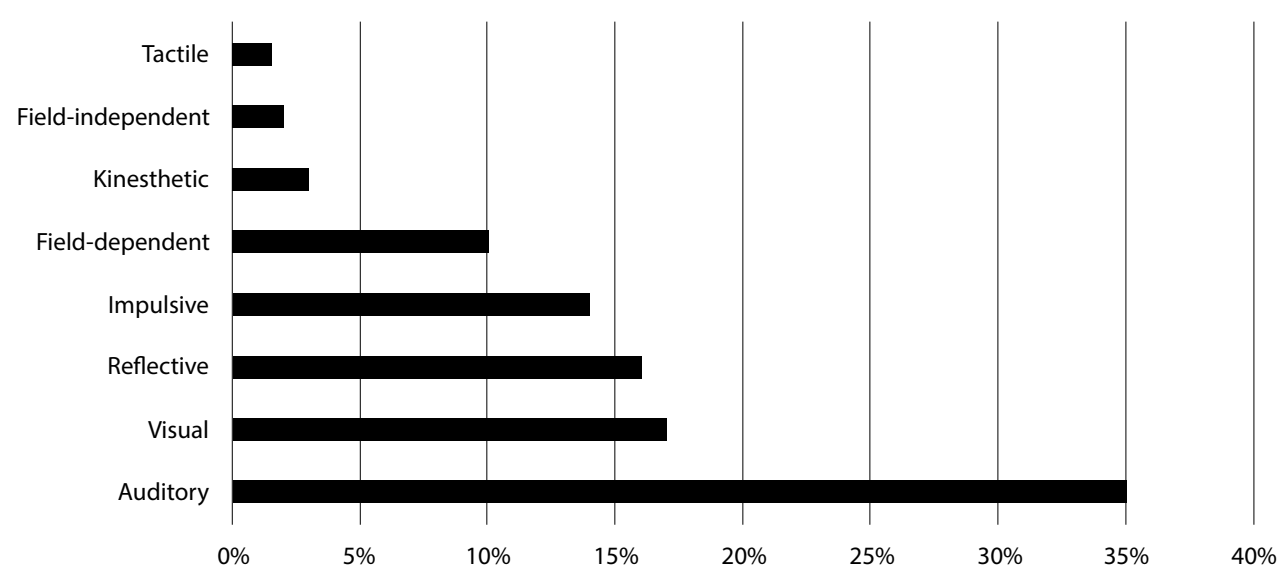

Figure 1. Respondents' preferences for language learning styles.

In addition, the respondents were asked to indicate the strategies enabling them to achieve better results when studying English individually. The majority (64\%) mentioned watching films and videos, listening to English songs and playing computer games proving that the compensation strategy is the most widely used strategy among university students; $21 \%$ of the respondents pointed out communication with foreigners, life abroad and travelling meaning that the social strategy prevails among them; $15 \%$ of the students responded that reading English books helps them achieve better results which means that the metacognitive strategy plays an important role in language learning for this group (see Figure 2). 


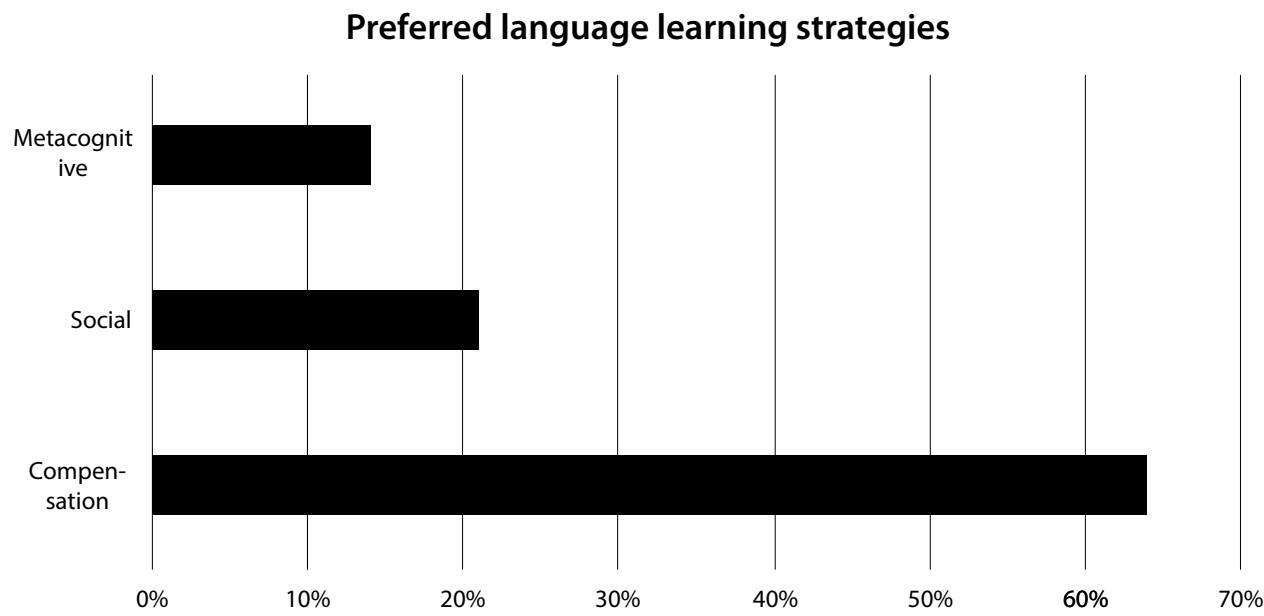

Figure 2. Respondents' preferences for language learning strategies.

\section{Conclusions}

The language learning process involves many variables, including language learning styles that determine learner's success. Despite the amount of researches on learning styles over the last few years, there is no clear evidence that any style generally prevails over others. There is not much to be done about the way we prefer to learn. The employed strategies are much more important in increasing the rate of progress in language learning. In a class made up of various learning styles, it is necessary for language teachers to identify and work on the diversity of learner differences. The students' learning preferences were identified in order to recognize their learning styles. The data was analyzed and the findings revealed that the students' learning styles can be categorized into auditory, visual and active learning. The results of the study indicated that compensation language learning strategy prevails among university students. Taking into consideration the research findings, the EFL teachers need to improve lesson planning to cater to the students' diverse learning styles.

On the whole, it is undeniable that the EFL students use diverse learning styles due to individual differences. Based on their learning preferences, students are both auditory and visual learners who specifically adopt a perceptual learning style.

To conclude, a discussion on students' diverse learning styles can have a significant impact on the teaching and learning process in the EFL education. Firstly, by having the knowledge of students' diverse learning styles, teachers would be able to identify students' learning styles and preferences in classrooms. Secondly, teachers could reflect on their own awareness of diverse learning styles that exist in the classroom. It is important to note that teachers too need to do the analysis of 
learning styles before approaching students differently. More importantly, teachers could, therefore, be ready to cater to the students' diverse learning styles. No single language methodology fits all students' styles, and strategies help determine a particular learner's ability and willingness to work within the framework of various instructional methodologies. Instead of choosing a specific instructional methodology, teachers would do better to employ a broad instructional approach, notably, the best version of the communicative approach that contains a combined focus on form and fluency. Such an approach allows for a deliberate and creative variety to meet the needs of all students in the class.

Teachers could benefit by assessing the use of learning styles and strategies of their students because such assessment leads to a greater understanding of styles and strategies. Also, the assessment is important for better awareness of their preferences and possible biases. This study seems to have a few limitations, especially in terms of variables and instrumentation. The size of the sample could also be expanded so as to produce more generalizable results.

\section{References}

Brown, H. (1994). Principles of Language Learning and Teaching. New Jersey: Prentice Hall. Retrieved on May 22, 2019 from http://esl.fis.edu/eltern/ advice/styles.htm

Chamot, A. U. (2005). Language Learning Strategy Instruction: Current Issues and Research. Annual Review of Applied Linguistics, 25, p. 112-130.

Cohen, A. D. (1998). Strategies in Learning and Using a Second Language. Essex, U.K.: Longman.

Nunan, D. (1997). Does Learner Strategy Training Make a Difference? Lenguas Modernas, 24, p. 123-142.

Oxford, R. L. (1999). Relationships between Learning Strategy Use and Language Proficiency in the Context of Learner Autonomy and Self-regulation.

Oxford, R. L. (2003). Learning Styles \& Strategies. Oxford, GALA. Retrieved May 15, 2019 from http://web.ntpu.edu.tw/ language/workshop/read2.pdf

Oxford, R. L. (2006). Language Learning Styles and Strategies: Concepts and Relationships. Retrieved on May 16, 2019 from https://www.degruyter.com/ view/j/iral.2003.41.issue-4/iral.2003.012/iral.2003.012.xml

Oxford, R. (2010). Language Learning Strategies in a Nutshell: Update and ESL Suggestions. Retrieved on May 22, 2019 from https://www.cambridge.org/ core/books/methodology-in-language-teaching/language-learning-strategies-in-anutshell-update-and-esl-suggestions/A95AC97E225C621183C4AD977104C33F

Purpura, J. (1999). Learner Characteristics and L2 Test Performance. In R. L. Oxford (Ed.), Language Learning Strategies in the Context of Autonomy. Synthesis of Findings from the International Invitational Conference on Learning Strategy Research (pp. 61-63), Teachers College, Columbia University, New York, NY. 
Razawi, N. A. et al. (2011). Students' Diverse Learning Styles in Learning English as a Second Language. International Journal of Business and Social Science, vol. 2 No. 19. Retrieved on May 23, 2019 from http://ijbssnet.com/journals/Vol_2 No_19_Special_Issue_October_2011/22.pdf

Vernon, Sh. (2016). How to Teach English for Different Learning Styles. Retrieved on May 21, 2019 from https://www.teachingenglishgames.com/Articles/ Learning_Styles.htm

Willing, K. (1994). Learning Strategies in Adult Migrant Education. National Centre for English Language Teaching and Research, Sydney.

Wong, L. C. Nunan, D. (2011). The Learning Styles and Strategies of Effective Language Learners. Author Links Open Overlay Panel. Retrieved on May 1, 2019 from https://www.sciencedirect.com/science/article/pii/S0346251X1100056X 


\section{STUDENTŲ UŽSIENIO KALBŲ \\ MOKYMOSI STILIAI IR METODAI}

\section{Dalia Gulbinskienė, doc. dr. Giedrè Valūnaitė Oleškevičienė}

\section{Santrauka}

Kiekvienas iš mūsų turi savo pageidaujamą užsienio kalbos mokymosi būdą, kurị lemia mūsų kultūrinis pagrindas, išsilavinimas bei mūsų asmenybẻ. Nèra aiškiu įrodymų, kad vienas mokymosi stilius yra geresnis nei kitas. Mes negalime padaryti labai daug, kad pakeistume tai, kaip mes norètume mokytis. Didžiausią itaką kalbos pažangai turi strategijos, naudojamos konkrečioje mokymosi situacijoje. Dažnai mes nežinome, kodèl sunku išmokti užsienio kalbą mokant konkrečiam mokytojui, o kitas, atrodo, paaiškina viską teisingu būdu. Šių neatitikimų priežastis gali būti mokymosi stilių skirtumai. Žmonès geriausiai mokosi, kai naudojamos strategijos yra glaudžiai suderintos su pageidaujamu mokymosi stiliumi. Kartais mes galime pagerinti savo mokymąsi žinodami, kokios yra mūsų stiprybès ir kas mums sekasi. Tačiau taip pat svarbu žinoti savo trūkumus, kad galėtume pagerinti ịgūdžius šiose srityse. Kai anglų kalbos mokytojai stengiasi pagerinti studentų darbo efektyvumą, jie turètų žinoti pagrindines mokymosi kategorijas, kurios geriausiai atitinka mokinių norą mokytis, ir pasitikrinti, ar jie laikosi siūlomų strategijų. Taigi, užsienio kalbų mokytojai gali padèti mokiniams plètoti savo mokymosi stiliaus nuostatas. Tyrime išnagrinèti įvairūs mokymosi stiliai ir strategijos, kurias naudoja tiriamojo Lietuvos universiteto studentai, besimokydami anglų kalbos. Tyrimas atskleidè, kad girdimasis kalbų mokymosi stilius ir kompensavimo strategija yra dominuojantys tarp studentų. 


\section{AUTORIŲ LYDRAŠTIS}

Autoriaus vardas, pavardè: Dalia Gulbinskienè

Mokslo laipsnis ir vardas: humanitarinių mokslų magistré

Darbo vieta ir pareigos: Generolo Jono Žemaičio Lietuvos karo akademijos Užsienio kalbų centro dėstytoja

Autoriaus mokslinių interesų sritys: didaktika, užsienio kalbų mokymas(is), profesinės anglų kalbos mokymas, suaugusiųjų mokymas, refleksyvusis mokymas, užsienio kalbų mokymosi motyvacija, tarpkultūrinis ugdymas

Telefonas ir el. pašto adresas: +37061641 033, dalia.gulbinskiene@lka.lt

Autoriaus vardas, pavardė: Giedrè Valūnaitė Oleškevičienè

Mokslo laipsnis ir vardas: mokslų daktarè (švietimo mokslai, socialinių mokslai)

Darbo vieta ir pareigos: Mykolo Romerio universitetas, Humanitariniu mokslų institutas, docentè

Autoriaus mokslinių interesų sritys: socialinių tyrimų metodologija, šiuolaikinès ugdymo filosofijos problemos, kūrybiškumo pletote šiuolaikinëje švietimo sistemoje, užsienio kalbos didaktika, verslo ir teisinès anglų kalbos mokymo(si) tyrimai, diskurso analizè, diskurso ryšiais anotuoti tekstynai, dalykinès anglų kalbos tyrimai, lingvistika ir vertimo tyrimai.

Telefonas ir el.pašto adresas: +370 68694 276, gvalunaite@mruni.eu

\section{AUTHORS' COVER LETTER}

Author's name and surname: Dalia Gulbinskienè

Academic degree and name: Master of Humanities

Workplace and position: Lecturer, Department of Foreign Languages, General Jonas Žemaitis Military Academy of Lithuania

Author's research interests: didactics, foreign language teaching at tertiary level, professional English language training, adult learning, reflective learning, language learning motivation, intercultural education

Telephone and e-mail address: +370 61641 033, dalia.gulbinskiene@lka.lt

Author's name and surname: Giedrè Valūnaitė Oleškevičienė

Academic degree and name: $\mathrm{PhD}$ in Education Science, Social Sciences

Workplace and position: Associate Professor, Institute of Humanities, Mykolas Romeris University

Author's research interests: social research methodology, modern education philosophical issues, creativity development in modern education system, foreign language teaching and learning, business and legal English teaching and learning, discourse analysis, discourse annotated corpora, professional English, linguistics and translation research

Telephone and e-mail address: +370 68694 276, gvalunaite@mruni.eu 